\title{
IS DIGITAL HEROIN CREATING DISTURBING BEHAVIORS AMONG CHILDREN?
}

\author{
Moderating Role of Smartphone Addicted Parents
}

Murtaza, Shah Ali - Molnár Edina

\section{Summary}

Addiction of cell phones, tablets and computers is creating disturbing behaviors among society members universally. The purpose of this study is to describe the influence of digital heroin on youngsters that are students of top Montessori schools and how their parent's addictive habits acts as a moderator. This research includes the survey of four hundred and fifty respondents, most of them are the parents of children aged between 3 to 8 years in Lahore, Pakistan. Gymboree (a Montessori academy by Beaconhouse), Lahore Grammar School and Choueifat was included in this survey. The results of the survey exhibit that overwhelming usage of digital gadgets has sudden and significant influence on the youngsters' bealth; the greater the addiction of parents towards smart phones, greater is the tendency of a child to demonstrate disturbing behavior. Children of this age are having more interaction with digital technology but there is a very fine line between bealthy and addictive usage. There are a lot of reasons why parents let their children use smart gadgets for a longer period of time, one of the reasons of which is easy parenting. This research can play a significant role for social science as well as for technological companies who need to realize that the real game lies in long term goodwill and not the short-term profitability through considering the drivers of youngsters's psychological problem.

Keywords: smart phones, digital heroin, smart phone addiction, disturbing behaviors JEL: M140, M150, M380

\section{A DIGITÁLIS HEROIN ZAVARÓ VISELKEDÉST VÁLT KI A FIATALOK KÖZÖTT?}

\section{Összefoglalás}

A mobiltelefonok, táblagépek és számitógépek függösége zavaró magatartást vált ki a társadalom tagjai körében. A tanulmány célja bemutatni a digitális heroin hatását a fiatalokra, akik a legjobb Montessori iskolák tanulói, és åt, hogy szüleik függóségi szokásai hogyan müködnek moderátorként. A kutatás négyszáaötven válaszadó felmérését foglalja magába, akik többnyire 3-8 éves gyermekek szülei a pakisz̧táni Labore-ban. A Gymboree (a Beaconhouse montessori akadémiája), a Lahore Gimnázium és a Choneifat kerrïl be felmérésbe. A felmérés eredményei azt mutatják, hogy a digitalis eszközö̈k nagymértékü használata birtelen és jelentösen befolyásolja a fiatalok. egészségét; minél nagyobb a szülók függösége az okostelefonok iránt, annál nagyobb a gyermek hajlama a zavaró magatartásra. Az ilyen korú gyermekek többféle kpacsolatban vannak a digitális technológiával, de az egészséges és az addiktiv használat kö̈zött nagyon finom a határ. Nagyon sok oka van annak, hogy a szülök hosszabb ideig engedik gyermekeiket használni az okos es₹közöket, egyik, fö ok a laza szülöi nevelés. 
Kulcsszavak: okostelefon, digitális heroin, okostelefon függóség, zavaró viselkedés JEL: M140, M150, M380

\section{Introduction}

The world we live in today is digitizing every day. Nearly everything we need and everything we do is in the palm of our hand. In the quest of getting smart in day to day activities, mankind has leveraged technology to surpass his/her physical limitations. From ordering food to playing official distant meetings and a lot more is now in the palm of your hand. Yes! We are talking about the revolutionizing invention of the $21^{\text {st }}$ century, the smart phones. There were 1.5 trillion digital interactions in 2014 per month from users across 172 countries (Chasin-Goldstein, 2014). This demonstrates that digital communication/interaction has become ubiquitous and these devices have become part of our daily routines. The excessive use of various electronic devices, in particular smartphones, adds to a growing uneasiness for potential harm affecting the health of today's youth. From a business management perspective, this addictive behavior of youth and families is a big concern for technology companies who foresee this addiction jeopardizing their long sustainability, brand loyalty and goodwill. Research shows that the overuse of smartphones correlates with various mental health concerns, such as anxiety, depression, stress, and low self-esteem (Panova-Carbonell, 2018). The public, policymakers, and health researchers have heightened concerns regarding children's unique vulnerability to exposure to wireless radiofrequency electromagnetic radiation emitted from smartphones and phone station antennae (American Academy of Pediatrics (AAP), 2016). Problematic mobile phone use (PMPU) is a more harmful phenomenon than being helpful, which results in negative outcomes.

Having said that, smart phone usage is also becoming society's biggest problem. Dependence on technology has impaired people's ability to interact with other people. Not only this, people are now glued to their smart phones all day because they find a substitute to nearly everything they need, in that device. They feel anxiety and depression when they don't have their handset. The most dangerous aspect of this dilemma is the kids who are getting prone to smart phone addiction. Its physical and psychological effects are same as that of alcohol or drug. When we talk about physical addiction, your body gets used to the stuff being used and gradually starts requiring increased amount of stuff to satisfy the needs being fulfilled by lesser amounts earlier.

\section{Smartphone Addiction}

Smartphone addiction is defined as a behavior characterized by excessive use of smartphones for the purpose of seeking relief, comfort or stimulation which leads to constant cravings when it is out of reach and sight (Butcot-Kim-Park, 2018). It is the phenomenon in which individuals get glued to their smartphones hence ignoring all other tasks in their lives (Goswami-Singh, 2016). There is growing evidence that the early introduction of digital media through the use of smartphones is irreversibly rewiring the brains of infants during crucial stages of development (Swingle, 2016). They are impacting children's activities and their behaviors drastically. These tendencies are comprised of traits of life disorders (cannot effectively manage daily life on account of smartphone usage), virtual-world orientation (being more satisfied with the virtual space within the smartphone than real life activities), withdrawal symptoms (anxiety and nervousness arising from being unable to use the smartphone), and tolerance building (an increase in the time spent 
using smartphones) (Moon-Choi, 2015). Kahyaoğlu, Kurt, Uzal, and Özdilek (2016) claim that the social life of people with higher smartphone addiction scores is negatively affected. Children also tend to attach themselves with the virtual would that they have formed with their smartphones and loose contact with the real world which alarming.

\section{Disturbing Behaviors}

Children nowadays start demonstrating disturbing behaviors once the usage of smartphones becomes intense. They can also express aggression once the smartphone is taken away from them which has been witnessed by many parents. These behaviors include not only the maladjustment to socialization, but also the lack of will to address these problems, the resulting personalities, and the deterrence of emotional development (Hong-Moon, 2013). Youngsters are whatever their parents make them. The source of positivity as well negativity is the parents of the child. They are the reproduction of their parents and peers with regards to practices, dispositions, reactions and identity characteristics. Children may also develop addictive smartphone usage habits if their parents are addictive smartphone users. Children force the parents to give them smartphones when they watch them using it. Smartphone and software companies make attractive GUI as well games so that children want to use it more and more. It is not just a coincidence that several companies choose child and juvenile age segment as a target. This is the segment which used to have, have and will always have a growth potential (Szúcs-Pólya, 2011). These children ask their parents to buy them tablets of their own so that they can have an uninterrupted experience. Hence, though it is tough to individually summarize the disturbing behaviors, they can come out in the form of hyperactivity, bullying, lying, depression, aggression etc. (Kim, 2013).

\section{Theoretical Framework \& Hypotheses Development}

Children's digital/smart gadget usage totally depends on the environment and the stimulus they are exposed to i.e. their parents. The key idea is that individuals learn by observing others' lead, demeanors, and consequences of those practices. „Many human conducts are discovered observationally by illustrating: from examining others, one structures a thought of how new practices are performed, and on later occasions this coded information fills in as a guide for action." (Bandura-Walters, 1977). In this postulation, the hidden hypothesis is the Social learning hypothesis by Albert Bandura which clarifies that a kid's advanced cell fixation affinity is impacted by their folk's PDA habit that inevitably prompts the youngster's irritating conduct. This hypothesis additionally shows that because of this addictive conduct of guardians and youngsters, there is a generous risk to portable organizations in the more drawn out run. Versatile organizations need to understand that there will be a period when individuals will quit utilizing their items or even quit getting them since they need a solid situation for kids for which they should change their own living example. One noteworthy change will be the disposing of advanced mobile phone devices and locate a sound option for their children as well. The kid's first establishment is his/her folks and he mirrors them thus building up specific practices.

The research comprises of an independent variable, a dependent and a moderating variable. Please find below the theoretical framework. 


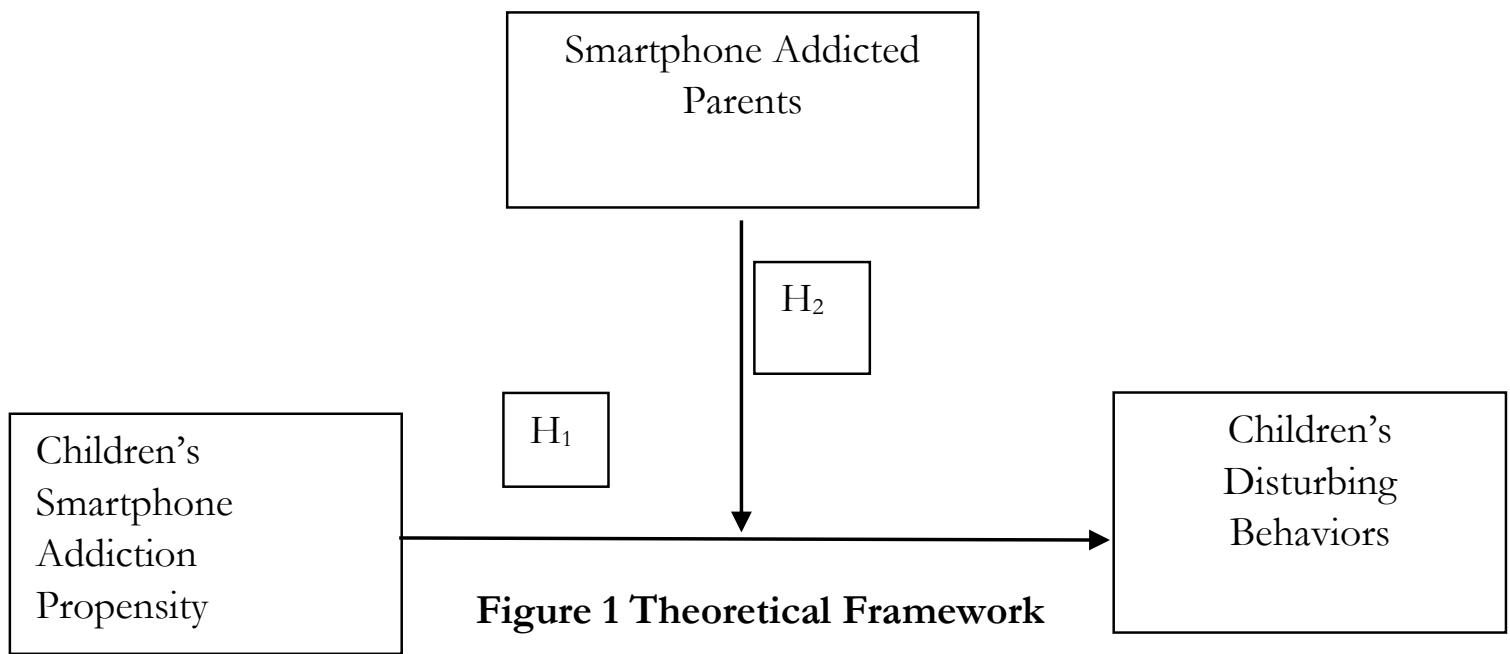

H1: There is a positive impact of Children's Smartphone Addiction Propensity on their disturbing behaviors,

H2: The impact of Children's Smartphone Addiction Propensity on their disturbing behaviors varies based upon the extent of parent's addiction towards smart phones.

\section{Materials and Methods}

In the survey, four hundred and fifty respondents, most of them are the parents of children aged between 3 to 8 years in Lahore, Pakistan. Gymboree (a Montessori academy by Beaconhouse), Lahore Grammar School and Choueifat was included in this survey. Mothers of children of age 38 years from Montessori and primary classes of three different schools (Gymboree, Choueifat and LGS) have been considered. Purposive sampling (critical case sampling) has been used based our own judgement since these are (a) high end schools of society, (b) they use digital gadgets in their teaching methodology and (c) all the children in these schools are having a smart tablet. Smart PLS has been used for data tabulation and analysis. Data has been collected through primary research.

The complete data collection process took more than a month for completion. Self-administered questionnaire has been used as a research tool and was distributed in all three schools. The questionnaire has been adopted using three separate research instruments already used by researchers to measure these three variables. The parent's smartphone addiction was measured by questions developed by National Information Society Agency (2013) and used in precious research by Hyun, Park, Cho and Kim (2013). The smartphone addiction tendency of children was measured by a questionnaire already used in research of Jo and Hwang (2014). The disturbing behaviors of children was measured through questions from Preschooler Behavior Questionnaire (PBQ) of Behar and Springfield (1974) used in a research by Feil, Walker and Severson (1995). 


\section{Analysis}

Two separate models have been used. The first one measures the influence of independent variable on the dependent variable and the second model measures the same impact in the presence of a moderator variable. Both models are linear in nature since the data collected through Likert scale questionnaire.

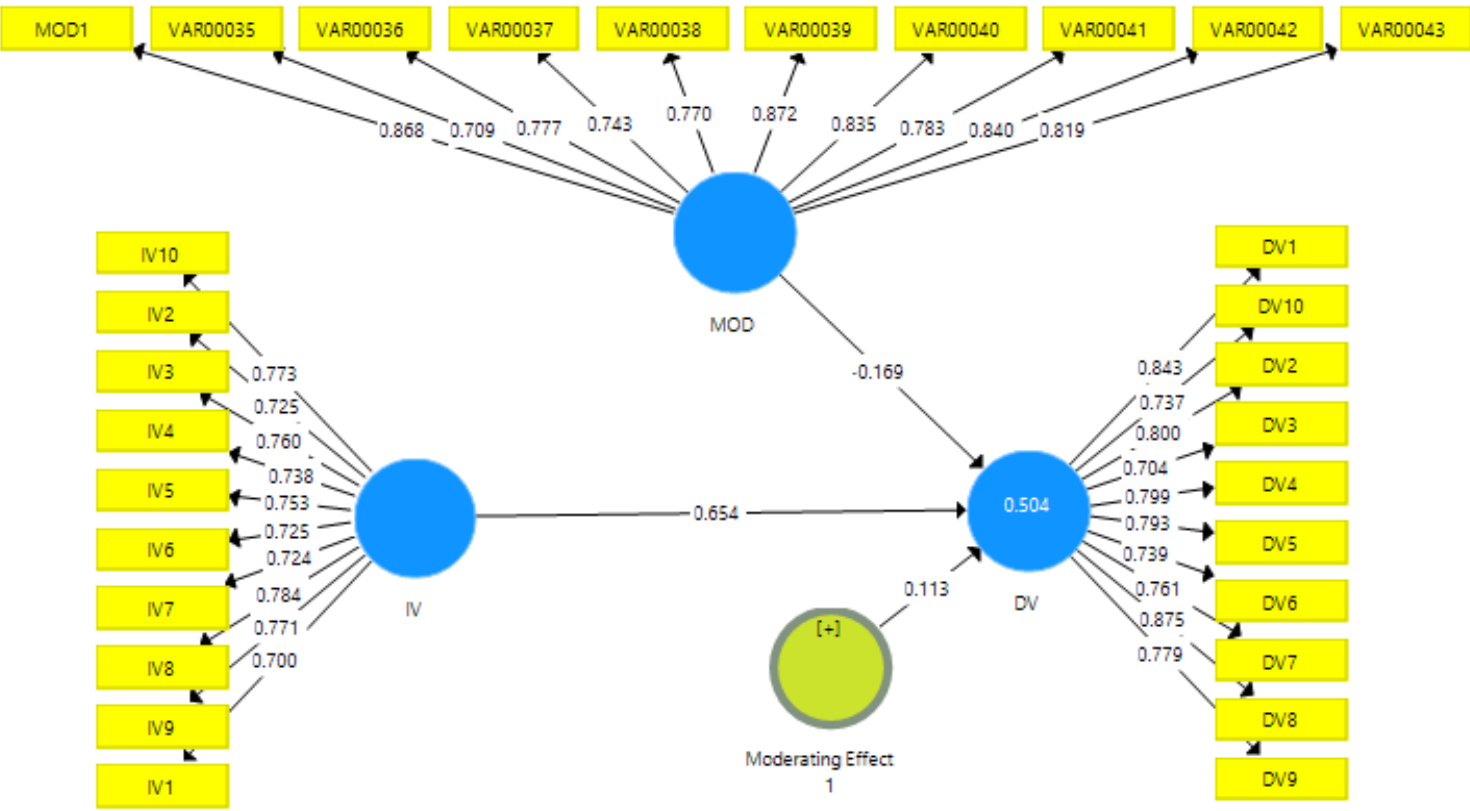

Figure 2 Structural Equation Model

\section{Reliability and Validity Test}

To measure the internal consistency of the items, reliability test has been run. Table 1 and Table 2 show Cronbach's alpha of inter item consistency as well as internal consistency in each item.

Table 1 Construct Reliability and Validity

\begin{tabular}{ccccc}
\hline Construct & $\begin{array}{c}\text { Cronbach's } \\
\text { Alpha }\end{array}$ & rho_A & $\begin{array}{c}\text { Composite } \\
\text { Reliability }\end{array}$ & $\begin{array}{c}\text { Average Variance Extracted } \\
\text { (AVE) }\end{array}$ \\
\hline DV & 0.930 & 0.933 & 0.941 & 0.616 \\
IV & 0.917 & 0.939 & 0.926 & 0.556 \\
MOD & 0.941 & 1.003 & 0.948 & 0.645 \\
Moderating & 1.000 & 1.000 & 1.000 & 1.000 \\
Effect 1 & & & & \\
\hline
\end{tabular}


Table 2 Discriminate Validity

\begin{tabular}{ccccc}
\hline Construct & DV & IV & MOD & Moderating Effect 1 \\
\hline DV & 0.785 & & & \\
IV & 0.681 & 0.746 & & \\
MOD & -0.170 & 0.000 & 0.803 & 1.000 \\
Moderating Effect 1 & 0.270 & 0.241 & -0.007 & \\
\hline
\end{tabular}

Table 3 Path Coefficients

\begin{tabular}{|c|c|c|c|c|c|}
\hline & Coefficient & $\begin{array}{l}\text { Sample Mean } \\
\text { (M) }\end{array}$ & STDEV & $\begin{array}{c}\text { T Statistics } \\
(|\mathrm{O} / \mathrm{STDEV}|)\end{array}$ & $\begin{array}{c}\mathrm{P} \\
\text { Value }\end{array}$ \\
\hline IV $\rightarrow$ DV & 0.654 & 0.655 & 0.023 & 28.988 & 0.000 \\
\hline MOD -> DV & 0.169 & 0.172 & 0.028 & 6.037 & 0.000 \\
\hline $\begin{array}{l}\text { Moderating Effect } 1 \rightarrow \\
\text { DV }\end{array}$ & 0.113 & 0.111 & 0.029 & 3.889 & 0.000 \\
\hline
\end{tabular}

Table 3 shows that all the $\mathrm{P}$ values are less than 0.05 which means the null hypotheses are rejected. A significant relation between IV and DV and a significant moderation effect in the existing relationship.

Table 4 Coefficient of Determination ( $R$ square)

\begin{tabular}{lcc}
\hline & R Square & Adjusted R Square \\
\hline DV & 0.504 & 0.501 \\
\hline
\end{tabular}

Table 4 shows the $\mathrm{R}$ square value determined by the data points around the fitted regression line. This tells us the goodness of fit for the model. The value of $\mathrm{R}$ square ranges from $0-1$ and a value of 0.504 shows that more than $50 \%$ variation is seen in the dependent variable explained by the independent variable.

\section{Results}

Hypothesis 1: There is a significant impact of Digital Heroin (children's smart phone addiction propensity) on children's disturbing behaviors. Also we can see that the impact of moderation on this relationship is also quite significant. This means that not only does the data support the first hypothesis of significant impact of independent variable on dependent variable but it also supports Hypothesis 2.

Hypothesis 2: There is a significant moderation effect on the dependent variable. The moderator, parent's smart phone addiction increases the impact of digital heroin on disturbing behaviors. Therefore, it can be summarized that the behavioral problems of the children increase with the increase in the usage of digital devices. Also the greater the smart phone addiction seen by parents, greater is the evidence for disturbing behaviors in children. 
Kids are getting presented to current devices at an early age regularly around 2-4 years old. Now and then little child's short of what one-year-old gains admittance to these devices. Guardians being the saint for their children are the fundamental motivation for children who endeavors to utilize these devices. The majority of the children learn by watching their folks when they are utilizing these contraptions. Children are utilizing these devices on consistent schedule for up to 3 hours per day. They use at school as well as home and this devours the real part of their day with no physical movement. They get chafed when requested to leave the device.

\section{Conclusions}

The motivation behind choosing this topic was to create awareness about this plague of society for parents as well for tech companies. A lot of children also undergo severe mental disorders like autism, depression, anxiety and the reason is that these kids have been given smart gadgets at a very early age, and since they have developed a strong relationship with their tablet instead of humans. This problem is quiet deep rooted in all classes i.e. lower middle, middle, upper middle and upper classes.

The business implications are critical for mobile phone businesses and this is the turning point in this industry. Mobile Industry needs to take into consideration, customer wellbeing and not just profits. A product which will eventually harm the consumer base will be discarded by the consumer after the harm/damage has been done. What will the tech companies do then? In order to sustain profitability, they need to preempt this situation with a proactive approach and come up with awareness programs to let consumers know the adverse effect of technology.

\section{Recommendations}

The suggestions of this examination are as per the following. Initial, a tweaked program ought to be implemented that objectives each level of grown-up's and also youngsters' cell phone fixation. The greater part of the in-danger grown-ups recognized their own danger of a cell phone dependence issue. As of now, at the administration level, there are no aversion projects and medications for the hazard gathering. More appropriate projects to counteract cell phone enslavement should be created for every dependence level. It is important to offer projects that help kids to feel more bolstered and appended in their associations with educators, on the grounds that the social maladjustment with instructors in schools causes challenges in by and large school modification which can result in conduct issues.

In the current situation where pandemic is prevailing across the globe, all the new changes experienced by people are the new normal. People have increased their mobile usage due to Covid19 lockdown situations in various countries. Organizations have also switched to work from home and a lot of working parents now spend more time on laptops and mobile phone which is a work related obligation. As mentioned earlier in the research, children imitate their parents and pick their habits from surroundings through observation. Once they see their parents spending more time on their gadgets, the tendency of getting prone to smartphone addiction in children will rise resulting in disturbing behaviors.

To curb the situation, it is always important to practice a digital detox at home for yourself and children. Realizing that more and more time is spent on gadget even for work, it is necessary to 
reduce the leisure time on these machines and give yourself a digital detox. Digital detox can by any activity which involves more engagement with people instead of machines. Making your children engage in a healthy physical activity is only possible of you are also ready to give up your smartphone for some time and participate with them.

\section{References}

[1.] American Academy of Pediatrics(2016). Cell phone radiation and children's health: What parent need to know. HealthyChildren.org. URL: https://www.healthychildren.org/English/safetyprevention/all-around/Pages/Cell-Phone-Radiation-Childrens-Health.aspx

[2.] Bandura, A. - Walters, R. (1977). Social learning theory, 2(3), 384-385. DOI: $\underline{10.1177 / 105960117700200317}$

[3.] Butcot, D. - Kim, N. - Park, K. (2018). Development and evaluation of smartphone detox proram for university students. International Journal of Contents, 14(4), 1-9. DOI: $10.1177 / 105960117700200317$

[4.] Chasin, J. - Goldstein, L. (2014). Comscore Media Description of Methodology for United States: Unified Digital Measurement. Accessed: 2017-03-31. URL: http://www.journalism.org/files/2014/03/comScore-Media-Metrix-Description-ofMethodology.pdf

[5.] Feil, E. - Walker, H. - Severson, H. (1995). The early screening project for young children with behavior problems. Journal of Emotional and Behavioral Disorders, 3(4), 194-202. DOI: $10.1177 / 106342669500300401$

[6.] Goswami, V. - Singh, D. (2016). Impact of mobile phone addiction on adolescent's life:A literature review. International Journal of Home Science, 2(1), 69-74.

[7.] Hong, H. - Moon, H. (2013). The effect of children's temperament, mother's parenting behavior and teacher-child relationships on children's behavior problems. The Journal of EcoEarly Childhood Education, 12(4), 245-274.

[8.] Hyun, E. - Park, E. - Cho, M. - Kim, T. (2013). Relationship among mother's smartphone addiction levels, maternal depression, and Young Children's problem behaviors . Korean Journal of Early Childhood Education, 33(5), 181-205. DOI: 10.18023/kjece.2013.33.5.008

[9.] Jo, J. - Hwang, H. (2014). Analysis of structural relationships among influential variables for the information ethics awareness and internet game addiciton inclination of preschoolers. The Journal of Korea Open Association for Early Chilhood Education, 19(3), 187-218.

[10.] Kahyaoğlu, -S., Kurt, S., Uzal, Ö., \& Özdilek, S. (2016). Effects of smartphone addiction level on social and educational life in health sciences students. Eurasian Journal of Family Medicine, 5(1), 13-19.

[11.] Kim, Y. Y. (2013). The association between infant's problem behavior and self-efficacy: Focusing on the mediating effects of self-regulation. Journal of Early Childhood Education \& Educare Welfare, 18(1), 136-153.

[12.] Moon, J. - Choi, J. (2015). Smartphone addiction tendency of elementary school students influencing school adjustment and academic achievement: Mediatiing effect of ADHD tendency. The Journal of Special Children Education, 17(1), 263-292. DOI: 10.21075/kacsn.2015.17.1.263

[13.] Panova T. - Carbonell, X. (2018). Is smartphone addiction really an addiction? Journal of Behavioral Addictions, 7(2), 252-259. DOI: $\underline{10.1556 / 2006.7 .2018 .49}$ 
[14.] Swingle, M. (2016). I-minds: How cell phones, computers, gaming, and social media are changing our brains, our behavior and the evolution of our species. Gabriola Island, BC Canada: New Society Publishers.

[15.] Szűcs, R., \& Pólya, É. (2011). Economic risk of childhood obesity. European Scientific Journal, $15,25-37$.

\section{Authors}

Murtaza Shah Ali

ORCID 0000-0002-1753-2447

$\mathrm{PhD}$

Scholar

University of Debrecen, Károly Inrgi Doctoral School

shahalimurtaxa@gmail.com

Molnár Edina

ORCID 0000-0002-8074-0724

College Professor

University of Debrecen

Institute of Management \& Organization Sciences

molnar.edina.phd@econ.unideb.hu 
Murtaza S. A. - Molnár E.

\section{Annexure}

Please find below the questionnaire used for the research.

\begin{tabular}{|c|c|c|c|c|c|c|}
\hline \multicolumn{2}{|c|}{ Items } & \multirow{2}{*}{$\begin{array}{c}\text { Strongly } \\
\text { disagree }\end{array}$} & \multirow{2}{*}{$\begin{array}{c}\text { Disagree } \\
2\end{array}$} & \multirow{2}{*}{$\begin{array}{c}\text { Neutral } \\
3\end{array}$} & \multirow{2}{*}{$\begin{array}{c}\text { Agree } \\
4\end{array}$} & \multirow{2}{*}{$\begin{array}{c}\begin{array}{c}\text { Strongly } \\
\text { Agree }\end{array} \\
5\end{array}$} \\
\hline 1 & Missing planned work due to smartphone use & & & & & \\
\hline 2 & $\begin{array}{l}\text { Having a hard time concentrating in class, while } \\
\text { doing assignments, or while working due to } \\
\text { smartphone use }\end{array}$ & 1 & 2 & 3 & 4 & 5 \\
\hline 3 & $\begin{array}{l}\text { Feeling pain in the wrists or at the back of the neck } \\
\text { while using a smartphone }\end{array}$ & 1 & 2 & 3 & 4 & 5 \\
\hline 4 & Won't be able to stand not having a smartphone & 1 & 2 & 3 & 4 & 5 \\
\hline 5 & $\begin{array}{l}\text { Feeling impatient and fretful when I am not holding } \\
\text { my smartphone }\end{array}$ & 1 & 2 & 3 & 4 & 5 \\
\hline 6 & $\begin{array}{l}\text { Having my smartphone in my mind even when I am } \\
\text { not using it }\end{array}$ & 1 & 2 & 3 & 4 & 5 \\
\hline 7 & $\begin{array}{l}\text { I will never give up using my smartphone even when } \\
\text { my daily life is already greatly affected by it. }\end{array}$ & 1 & 2 & 3 & 4 & 5 \\
\hline 8 & $\begin{array}{l}\text { Constantly checking my smartphone so as not to miss } \\
\text { conversations between other people on Twitter or } \\
\text { Facebook }\end{array}$ & 1 & 2 & 3 & 4 & 5 \\
\hline 9 & Using my smartphone longer than I had intended & 1 & 2 & 3 & 4 & 5 \\
\hline 10 & $\begin{array}{l}\text { The people around me tell me that I use my } \\
\text { smartphone too much. }\end{array}$ & 1 & 2 & 3 & 4 & 5 \\
\hline 11 & $\begin{array}{l}\text { My child's school grades dropped due to excessive } \\
\text { smart phone/tablet use }\end{array}$ & 1 & 2 & 3 & 4 & 5 \\
\hline 12 & $\begin{array}{l}\text { My child has a hard time doing what he /she has } \\
\text { planned(study, homework, or after school classes) } \\
\text { due to using smart phone/tablet }\end{array}$ & 1 & 2 & 3 & 4 & 5 \\
\hline 13 & $\begin{array}{l}\text { Family or friends complain that my child uses } \\
\text { smartphone/tablet too much }\end{array}$ & 1 & 2 & 3 & 4 & 5 \\
\hline 14 & $\begin{array}{l}\text { Smartphone/tablet does not distract my child from } \\
\text { studies }\end{array}$ & 1 & 2 & 3 & 4 & 5 \\
\hline 15 & $\begin{array}{l}\text { Spending time with smartphone/tablet is more } \\
\text { enjoyable for my child than spending time with } \\
\text { family and friends }\end{array}$ & 1 & 2 & 3 & 4 & 5 \\
\hline 16 & $\begin{array}{l}\text { It is painful for my child when he/she is not allowed } \\
\text { to use smartphone/tablet }\end{array}$ & 1 & 2 & 3 & 4 & 5 \\
\hline 17 & $\begin{array}{l}\text { My child gets restless and nervous when he/she is } \\
\text { without smartphone/tablet }\end{array}$ & 1 & 2 & 3 & 4 & 5 \\
\hline 18 & $\begin{array}{l}\begin{array}{l}\text { My child panics when he cannot use his } \\
\text { smartphone/gadget }\end{array} \\
\end{array}$ & 1 & 2 & 3 & 4 & 5 \\
\hline 19 & Using my smartphone longer than I had intended & 1 & 2 & 3 & 4 & 5 \\
\hline 20 & $\begin{array}{l}\text { My child cannot control his/her smartphone/tablet } \\
\text { usage time }\end{array}$ & 1 & 2 & 3 & 4 & 5 \\
\hline 21 & $\begin{array}{l}\text { Your child is restless. Runs about or jumps up and } \\
\text { down. Doesn't keep still }\end{array}$ & 1 & 2 & 3 & 4 & 5 \\
\hline 22 & Your child destroys own and other's belongings & 1 & 2 & 3 & 4 & 5 \\
\hline 23 & Your child fights with other children & 1 & 2 & 3 & 4 & 5 \\
\hline 24 & Your child is not much liked by other children & 1 & 2 & 3 & 4 & 5 \\
\hline 25 & $\begin{array}{l}\text { Your child appears miserable, unhappy, tearful and } \\
\text { distressed. }\end{array}$ & 1 & 2 & 3 & 4 & 5 \\
\hline 26 & Your child bites nails or fingers & 1 & 2 & 3 & 4 & 5 \\
\hline 27 & Your child is disobedient & 1 & 2 & 3 & 4 & 5 \\
\hline 28 & $\begin{array}{l}\text { Your child has poor concentration or short attention } \\
\text { span }\end{array}$ & 1 & 2 & 3 & 4 & 5 \\
\hline 29 & Your child has stutter or stammer & 1 & 2 & 3 & 4 & 5 \\
\hline 30 & Your child has other speech difficulty & 1 & 2 & 3 & 4 & 5 \\
\hline
\end{tabular}


